\title{
Publisher Correction: A community-based transcriptomics classification and nomenclature of neocortical cell types
}

Rafael Yuste Dichael Hawrylycz DiD, Nadia Aalling D , Argel Aguilar-Valles, Detlev Arendt, Ruben Armananzas Arnedillo (D), Giorgio A. Ascoli, Concha Bielza, Vahid Bokharaie, Tobias Borgtoft Bergmann D, Irina Bystron, Marco Capogna D, Yoonjeung Chang, Ann Clemens D, Christiaan P. J. de Kock, Javier DeFelipe, Sandra Esmeralda Dos Santos, Keagan Dunville, Dirk Feldmeyer Dichárd Fiáth, Gordon James Fishell, Angelica Foggetti, Xuefan Gao, Parviz Ghaderi $\mathbb{D}$

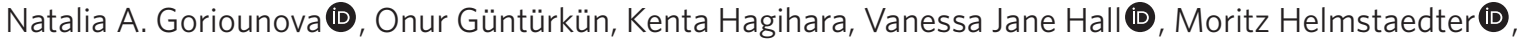
Suzana Herculano, Markus M. Hilscher DD, Hajime Hirase, Jens Hjerling-Leffler (D), Rebecca Hodge (D), Josh Huang (D), Rafiq Huda D, Konstantin Khodosevich, Ole Kiehn D, Henner Koch, Eric S. Kuebler D, Malte Kühnemund, Pedro Larrañaga, Boudewijn Lelieveldt, Emma Louise Louth, Jan H. Lui (D), Huibert D. Mansvelder (D), Oscar Marin (D), Julio Martinez-Trujillo D , Homeira Moradi Chameh, Alok Nath D, Maiken Nedergaard D, Pavel Němec Di, Netanel Ofer (D), Ulrich Gottfried Pfisterer, Samuel Pontes Dilliam Redmond Di, Jean Rossier, Joshua R. Sanes (D), Richard Scheuermann D, Esther Serrano-Saiz, Jochen F. Steiger, Peter Somogyi, Gábor Tamás $\mathbb{D}$, Andreas Savas Tolias $\mathbb{D}$ Maria Antonietta Tosches D, Miguel Turrero García (D), Hermany Munguba Vieira, Christian Wozny (D) Thomas V. Wuttke D, Liu Yong (D), Juan Yuan, Hongkui Zeng D and Ed Lein D

Correction to: Nature Neuroscience https://doi.org/10.1038/s41593-020-0685-8, published online 24 August 2020.

In the version of this article initially published, author Thomas V. Wuttke's affiliation was shown incorrectly. Dr. Wuttke is affiliated with University of Tübingen, Tübingen, Germany. The error has been corrected in the PDF and HTML versions of this article.

\footnotetext{
(i) Open Access This article is licensed under a Creative Commons Attribution 4.0 International License, which permits use, sharing, adaptation, distribution and reproduction in any medium or format, as long as you give appropriate credit to the original author(s) and the source, provide a link to the Creative Commons license, and indicate if changes were made. The images or other third party material in this article are included in the article's Creative Commons license, unless indicated otherwise in a credit line to the material. If material is not included in the article's Creative Commons license and your intended use is not permitted by statutory regulation or exceeds the permitted use, you will need to obtain permission directly from the copyright holder. To view a copy of this license, visit http://creativecommons.org/licenses/ by/4.0/
}

Published online: 4 December 2020

https://doi.org/10.1038/s41593-020-00768-3

๑ The Author(s) 2020 